\title{
Probiotics and Inhibition of Clostridium difficile Toxin
}

\author{
Jina Lim, Kwang-Hyun Kim and Sejong Oh ${ }^{*}$ \\ Division of Animal Science, Chonnam National University, Gwangju, Korea
}

\begin{abstract}
The definitions of international authorized probiotics are live microorganisms that, when administered in adequate amounts, confer a health benefit on the host. The scientific basis for the prevention and treatment of bowel disease among the functions of probiotics has only recently been established. Probiotics, which are actively studied, are lactic acid bacteria, especially Lactobacillus and Bifidobacterium species. The $C$. difficile toxin is controlled by quorum sensing, which causes intestinal disease and other gastrointestinal disorders, leading to antibiotic-associated diarrhea. The use of probiotics for prevention and treatment has been discussed in this review.
\end{abstract}

\section{Keywords}

Clostridium difficile, probiotics, quorum sensing, toxin

\section{Toxin of Clostridium difficile and C. difficile-associated diarrhea}

Clostridium difficile (C. difficile) was initially named Bacillus difficilis by Hall and O'Toole in 1935. It was first isolated from the stool of newborns and called "difficile" because it was difficult to culture (Schroeder, 2005). Later, C. difficile was found to be affiliated with the class Clostridia and the binomial name was changed to "Clostridium difficile." It was initially considered non-pathogenic bacterium. However, in 1978, it was reported to caused antibiotic-associated pseudomembranous colitis (Bartlett et al., 1978; Tedesco et al., 1974).

Received: 4월 30일, 2016 Revised: 5월 12일, 2016 Accepted: 5월 15일, 2016

*Corresponding author : Sejong Oh, Division of Animal Science, Chonnam National University, Gwangju, Korea. Tel: +82-062-530-2116

Fax: $+82-062-530-2129$

E-mail: soh@jnu.ac.kr
C. difficile is an exotoxin-producing (toxin A and B), gram-positive, rod-shaped bacterium. It has the ability to grow under an anaerobic conditions, while the spores can only survive under aerobic conditions. Spore formation increases the probability of $C$. difficile infection (CDI). C. difficile is transmitted via the fecal-oral route in the form of spores or whole cells and hands of the healthcare providers between patients in hospitals (Shaughnessy et al., 2011). The number of CDI has been rising steadily worldwide along with increasing morbidity and mortality over time. In 2003, CDI was found to be most prevalent disease in Canada, leading to the worldwide recognition of the threat of CDI. In Quebec, the number of severe cases of CDI quadrupled in 2003 compared to that in the period between

This is an Open Access article distributed under the terms of the Creative Commons Attribution Non-Commercial License (http://creativecommons.org/ licenses/by-nc/3.0) which permits unrestricted non-commercial use, distribution, and reproduction in any medium, provided the original work is properly cited. 
1991 and 2002 (Kelly and LaMont, 2008). In children, the number of severe cases of CDI has been reported to be continuously to increasing, from 3,565 cases in 1997 to 7,779 cases in 2006 (Zilberberg et al., 2010). The incidence of CDI is at an annual rate of approximately 3 million cases in the United States (Schroeder, 2005). From 2003 to 2006, the number of CDI occurrences and death In Austria increased significantly from 977 to 2,192 and from 80 to 150, respectively (Kuijper et al., 2008). The first outbreaks of C. difficile 027 occurred in South Korea, Hong Kong, and Costa Rica between 2008 and 2010 (Quesada-Gomez et al., 2010; Tae et al., 2009; Cheng et al., 2009). Increase in the incidence and severity of CDI can be attributed to a newly discovered strain of $C$. difficile strain BI/NAP1/027 (designated restriction endonuclease analysis type BI, North American pulsed-field gel electrophoresis type 1 (NAP1), polymerase chain reaction (PCR) ribotype 027) (McDonald et al., 2005). CDI due to the new strain B1/NAP1/027 rapidly increased after 2000. The expression of $t c d A$ and $t c d B$ that encoded toxin $A$ and toxin B was higher in $C$. difficile 027 than in other $C$. difficile strains. Therefore, $C$. difficile 027 causes more severe colitis and mortality than those caused by other strains (Fig. 1) (Clements et al., 2010). C. difficile BI/NAP1/ 027 has several characteristics such as $t c d C$ (a negative regulator of $C$. difficile toxin production) down-regulation and higher fluoroquinolone resistance (Clements et al., 2010). Therefore, C. difficile 027 expresses higher levels of $\operatorname{tcd} A$ (16-fold) and $\operatorname{tcdB}$ (23-fold) than that by the nother toxin type $O$ strain, and causes more severe colitis and higher mortality than those caused by other strains (Warny et al., 2005).

CDI occurs mainly in patients who have disturbances in the intestinal microbiota because of antibiotics. Infection occurs primarily in hospitals. C. difficile attaches to the mucus layer and enterocytes of patients with the aid of proteases and causes colonization. C. difficile secretes toxins to damage the colonic mucosa, and when the patient cannot produce antibodies to the toxin, clinical manifestations appear (Fig. 2) (Deneve et al., 2009). Alteration of intestinal microflora by antibiotics enables the overgrowth and dominance of pathogenic $C$. difficile in the gastro-intestinal environment and triggers $\mathrm{CDI}$ via the production of toxins A and B to destroy intestinal cells (Johnson and Gerding, 1998). CDI also has several risk factors, and the most important ones are advanced age

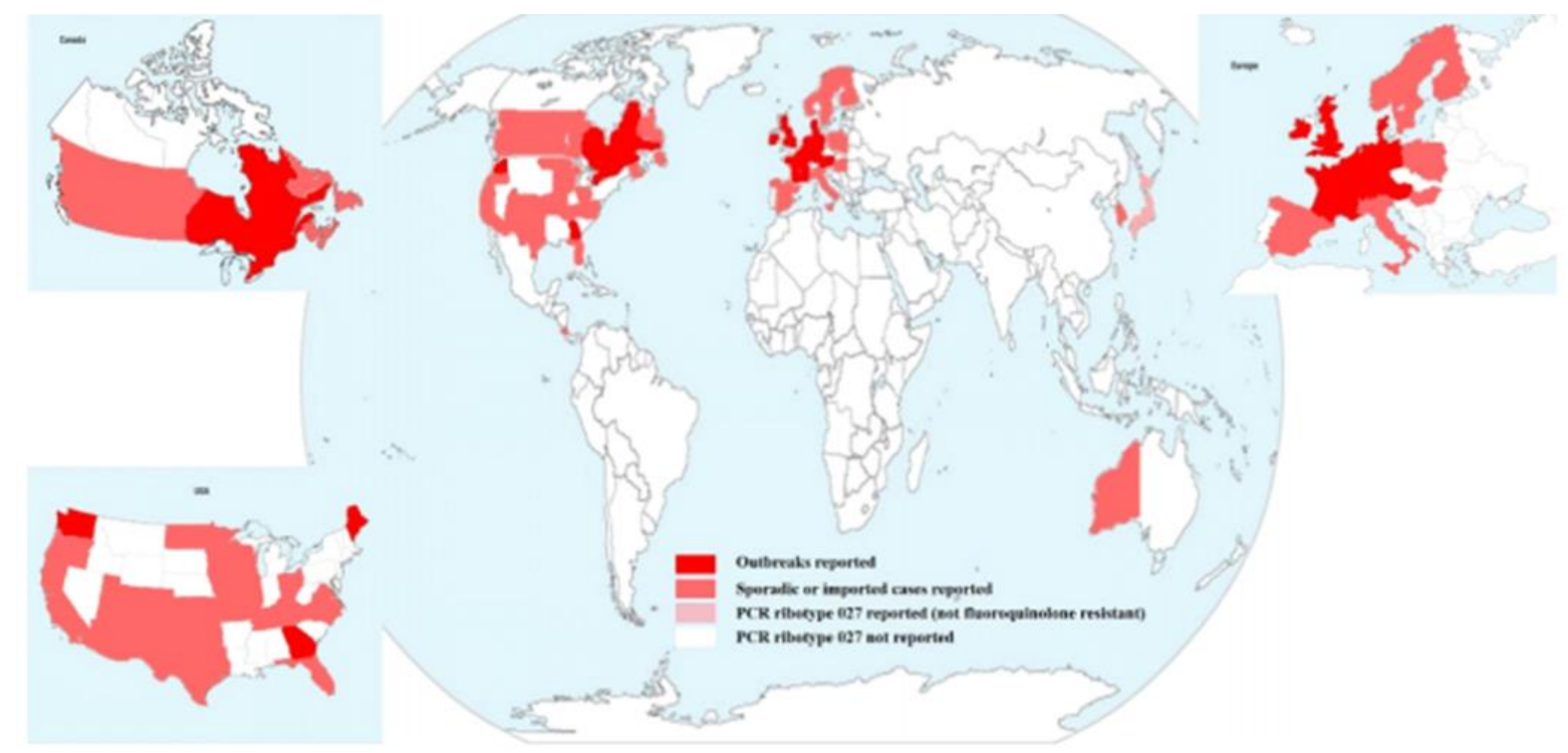

Fig. 1. Worldwide CDI occurrence of $C$. difficile PCR ribotype 027 Adapted from Clements et al., 2010 


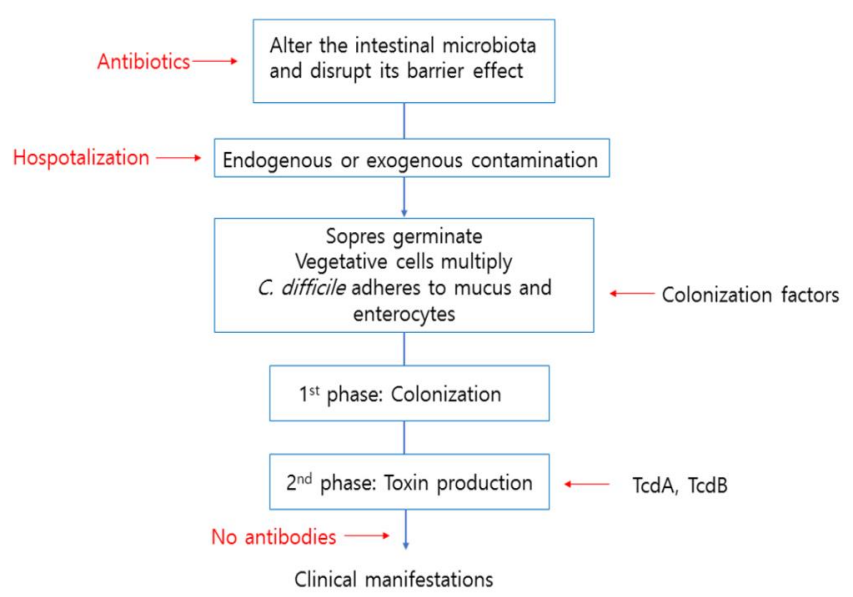

Fig. 2. Infection process of $C$. difficile Adapted from Deneve et al., 2009

and excessive use of antibiotics. Among patients infected with $C$. difficile, those who are 65 years of age or older and exposed to many antibiotics display the following progression of symptoms: inflammatory lesions, formation of pseudomembranous in the colon, toxic-megacolon or bowel perforation, sepsis, shock, and death (Fig. 3) (Rupnik et al., 2009).

The pathogenicity locus (PaLoc) of $C$. difficile consists of

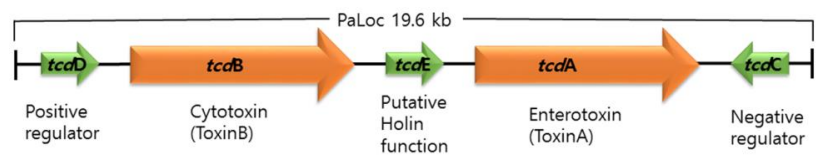

Fig. 4. Pathogenicity locus of $C$. difficile Adapted from Carter et al., 2012

$t c d A$, and $t c d B$ and accessory genes $t c d C$, tcdD, and $t c d E$ (Fig. 4) (O'Connor et al., 2009). TcdA and $t c d B$ encode toxins $\mathrm{A}$ and $\mathrm{B}$, which are the major toxins produced by C. difficile (Braun et al., 1996). C. difficile overgrowth occurs in the intestine after destruction of the normal intestinal flora, and it produces toxin A (308 kDa) and toxin B $(270 \mathrm{kDa})$. Toxin A enters the cells by endocytosis with the help of toxin $\mathrm{B}$. Toxin B binds preferentially to the cell membrane and causes cytoskeletal changes, resulting in disruption of tight junctions and loosening of the epithelial barrier. In addition, toxins $A$ and $B$ inactivate the Rho protein in the cytosol. Rho proteins functions by regulating the intestinal epithelial barrier, cell movements, intercellular junctions, immune cell migrations, and standard cellular functions (Jank et al., 2007). Rho proteins are modified by the glucosyltransferases of

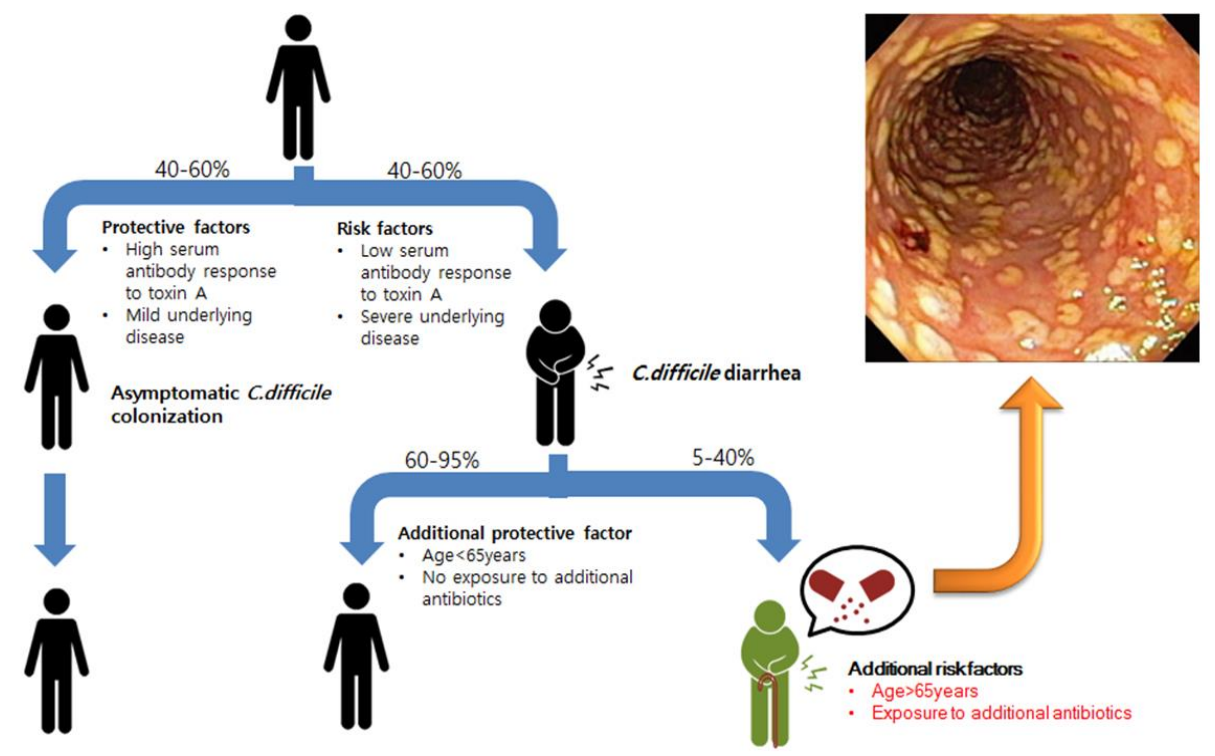

Fig. 3. Protective and risk factors of $C$. difficile-associated diarrhea Adapted from Poutanen and Simor, 2004 


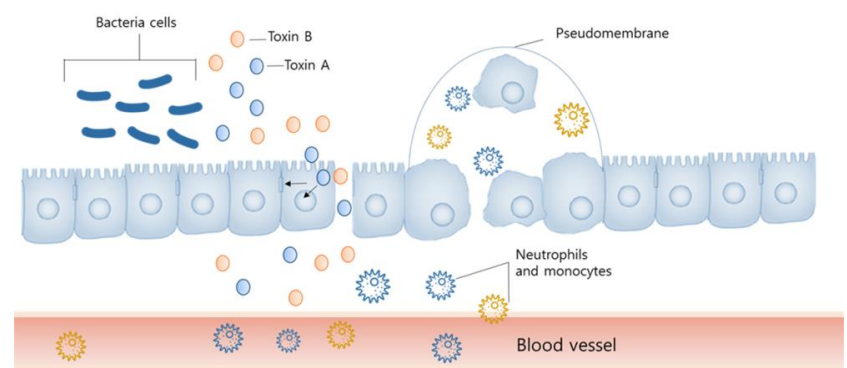

Fig. 5. Pathogenesis mechanism of $C$. difficile Adapted from Maja Rupnik et al., 2009

C. difficile toxins that inhibit GTPases activation by GEF. Inhibition of GTPases, which regulate intracellular actin dynamics, induces the weakening of cell junctions. Both toxins are cytotoxic and induce the release of various immunomodulatory mediators from epithelial cells, phagocytes, and mastocytes and cause the inflammation and the accumulation of neutrophilic leukocytes (Fig. 5) (Herrmann et al., 1998; Sehr et al., 1998; Jank et al., 2007, Martin-Verstraete et al., 2016). C. difficile toxin production decreases in the exponential phase and increases in the stationary phase because tcdC (negative regulator of $C$. difficile toxins) is up-regulated and $t c d D$ (positive regulator of $C$. difficile toxins) is down-regulated in exponential phase. Therefore, $t c d C$ and $t c d D$ regulate $C$. difficile toxin production (Hundsberger et al., 1997; Dupuy and Sonenshein, 1998).

\section{Toxin production and quorum sensing of $C$. difficile}

Quorum sensing (QS) is a bacterial cell-to-cell communication process, which regulates gene expression in response to cell number fluctuations (Fuqua et al., 1994). QS is involved in the production and detection of extracellular signaling molecules, known as autoinducers. Autoinducers regulate cell responses such as cell division and production of virulence factors (Xavier and Bassler, 2003). Secreted autoinducers regulate the expression of specific genes in accordance to the cell density. Gram-positive and gram-negative bacteria regulate various activities using QS, such as

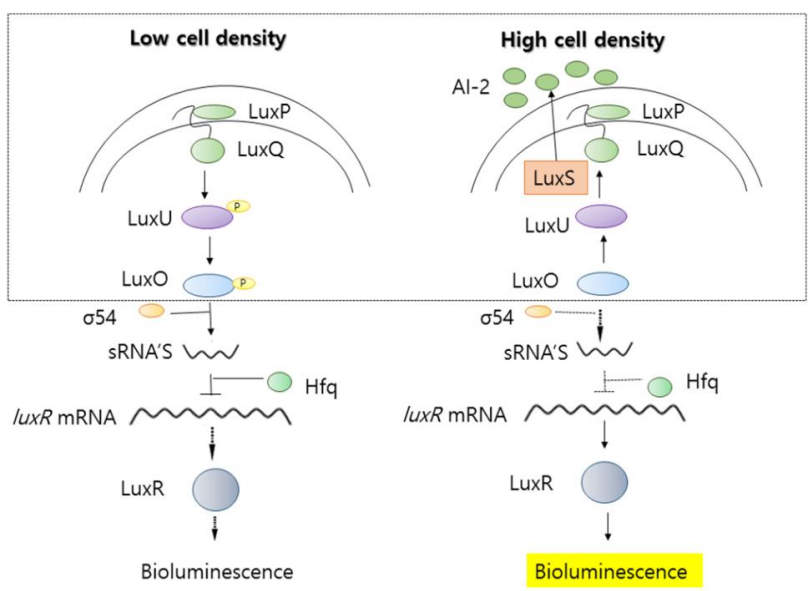

Fig. 6. Quorum sensing mechanism of $V$. harveyi. Solid line allow, active path; Dotted line allow, inactive path. Adapted from Banik et al., 2009

symbiosis, virulence, competence, conjugation, antibiotic production, motility, sporulation, and biofilm formation (Miller and Bassler, 2001; Waters and Bassler, 2005). QS was first observed in Vibrio fischeri and Vibrio harveyi (Nealson and Hastings, 1979). V. harveyi produces an acyl-homoserine lactones (acyl-HSL) autoinducer-1 (AI-1), which associates with the grampositive two-component phosphorelay system and produces and detects the autoinducer-2 (AI-2). Various gram-positive and gram-negative bacteria have a luxS quorum sensing system that produces and detects $\mathrm{AI}-2$ (Xavier and Bassler, 2003). LuxS QS in V. harveyi consists of the following mechanisms. At low cell densities, luxO is phosphorylated to control the production of multiple small RNA that inhibits post-transcriptional translation of the QS master regulatory protein ( $(u x R)$. In contrast, lux $S$ activated at high cell densities produces AI-2, and decreased production of small RNA activates luxR. This activation increases expression of the light-emitting gene of $V$. harveyi (Fig. 6) (Banik et al., 2009). Unlike HSL and other oligopeptide autoinducers, all AI-2-producing bacteria have identical a biosynthetic pathways, chemical intermediates, and AI-2 molecules (Miller and Bassler, 2001). These findings suggest that $\mathrm{AI}-2$ is a universal signal that enables intercellular communication. $\mathrm{AI}-2$ regulates the virulence factors of $C$. perfringens, motility of Escherichia coli EHEC (O127:H6), and biofilms of Salmonella Typhi (Table 1). 
Table 1. Gene and functions controlled by luxS in bacteria

\begin{tabular}{|c|c|c|}
\hline Species & Functions regulated by luxS & Genes regulated by luxS \\
\hline $\begin{array}{c}\text { Actinobacillus } \\
\text { actinomycetemcomitans }\end{array}$ & Virulence factor: leukotoxin, iron acquisition & afuA \\
\hline Borrelia burgdorferi & $\begin{array}{l}\text { Expression of many proteins on } \\
\text { two-dimensional-gels ErpA, }-1 \text { and }-\mathrm{N} \text { proteins }\end{array}$ & \\
\hline Campylobacter jejuni & Motility & \\
\hline Clostridium perfringens & Virulence factors: alpha, kappa and theta toxins & pfo \\
\hline Escherichia coli W3110 & Cell division, DNA processing, cell shape and morphology & 242 genes (microarray) \\
\hline Escherichia coli EHEC (0157:H7) & $\begin{array}{c}\text { Virulence factors: } \\
\text { type-III secretion, Shiga toxin, } \\
\text { flagella, motility, cell division }\end{array}$ & $\begin{array}{l}\text { LEE operon, stx, ptsN, sulA, } \\
f l h D, \text { fli } A \text {, fliC, mot } A, \text { qse } A, \\
\text { qseBC } 404 \text { genes (microarray) }\end{array}$ \\
\hline Escherichia coli EHEC (0127:H6) & Motility (flagellin expression) & \\
\hline Neisseria meningitides & Bacteremic infection & \\
\hline Photorhabdus luminescens & Carbapenem biosynthesis & cpm \\
\hline Porphyromonas gingivalis & $\begin{array}{l}\text { Virulence factors: } \\
\text { protease, hemagglutinin activities, hemin acquisition }\end{array}$ & uvrB, hasF \\
\hline Salmonella Typhi & Biofilms & \\
\hline Salmonella Typhimurium & Al-2 $A B C$ transport system & IsrACDBFGE \\
\hline Shigella flexneri & Transcription factors involved in controlling virulence & virB \\
\hline Streptococcus pyogenes & Virulence factors: secreted protease hemolysin & speB and sag $A$ \\
\hline Vibrio cholera & $\begin{array}{c}\text { Virulence factors: } \\
\text { Cholera toxin, toxin-coregulated pilus }\end{array}$ & $\begin{array}{l}t c p P, t c p A, c t x A B \sim 70 \\
\text { virulence genes (microarray) }\end{array}$ \\
\hline Vibrio harveyi & Light production, colony morphology, siderophore producton & IUxCDABE \\
\hline
\end{tabular}

EHEC, enterohemorrhagic E. coli; EPEC, enteropathic E. coli

(Adapted from Xavier and Blassler, 2003)

\section{Probiotics}

According to Gismondo et al. (1999), probiotics are live microorganisms that provide health benefits to people and animals when consumed. Probiotics are normally found in foods and dairy products. Although there are many probiotic bacteria, Lactobacillus and Bifidobacterium are mainly used (Kekkonen, 2008). The probiotic mechanism of action is as follows: Probiotics suppress growth and consequent adherence of pathogenic bacteria to the intestinal wall and aid the immune system by improving intestinal wall function (Zareie et al., 2006). Several probiotic strains promote the production of protective cytokines, such as IL-10 and TGF-beta, and inhibit the production of cytokines, such as TNF, that cause inflammatory responses. Probiotics have been reported to relieve allergies and antibiotic-associated diarrhea, inhibit bacterial vaginosis, and reduces blood cholesterol (Cuello-Garcia et al., 2015; McFarland, 2006; Borges et al., 2014; Ooi and Liong, 2010).

Recently, Lactobacillus strains and Saccharomyces boulardii have been reported to effectively prevent inflammatory bowel diseases and CDI in high-risk patients on antibiotics (Katz, 2006).

The inactivated lactic acid bacterium product has higher safety and stability than the live bacterium product. It can be stored easily because of its high stability, and the product distribution period, therefore, can be extended. Heat-inactivated Lactobacillus strains do not grow and, 
therefore, differ from live bacteria. The lysate resulting from heat treatment has antibacterial activity and consists of cell components such as the cytoplasm, cell wall, bacteriocins, polysaccharides, and organic acids. In recent years, inactivated Lactobacillus strains have been produced industrially to be used as probiotics. They can be used as raw materials for the production of cosmetics, and in fields where live bacteria have been applied (Seo et al., 2010).

\section{References}

1. Banik SK, Fenley AT, and Kulkarn RV. (2009) A model for signal transduction during quorum sensing in Vibrio harveyi. Phys. Biol. 6, 1-18.

2. Bartlett JG, Chang TW, and Gurwitt M. (1978) Antibiotic associated pseudomembranous colitis due to toxin producing Clostridia. N. Engl. J. Med. 298, 531-534.

3. Braun V, Hundsberger T, Leukel P, Sauerborn M, and von Eichel-Streiber C. (1996) Definition of the single integration site of the pathogenicity locus in Clostridium difficile. Gene. 181, 29-38.

4. Carter GP, Rood JI, and Lyras D. (2012) The role of toxin A and toxin B in the virulence of Clostridium difficile. Trends Microbiol. 20, 21-29

5. Cheng VC, Yam WC, Chan JF, To KK, Ho PL, and Yuen KY. (2009) Clostridium difficile ribotype 027 arrives in Hong Kong. Int. J. Antimicrob. Agents. 34, 492-493.

6. Clements AC, Maqalhaes RJ, Tatem AJ, Paterson DL, and Riley TV. (2010) Clostridium difficile PCR ribotype 027: assessing the risk of further worldwide spread. Lancet Infect. Dis. 10, 395-404.

7. Cuello-Garcia CA, Brożek JL, Fiocchi A, Pawankar R, Yepes-Nuñez JJ, Terracciano L, Gandhi S, Agarwal A, Zhang Y, and Schünemann HJ. (2015) Probiotics for the prevention of allergy: A systematic review and meta-analysis of randomized controlled trials. J. Allergy Clin. Immunol. 136, 952-961.

8. Deneve C, Janoir C, Poilance I, Fantinato C, and
Collignon A. (2009) New trends in Clostridium difficile virulence and pathogenesis. Int. Antimicrob. Agents. 1, S24-28.

9. Dupuy B, and Sonenshein AL. (1998) Regulated transcription of Clostridium difficile toxin genes. Mol. Microbiol. 27, 107-120.

10. Fuqua WC, Winans SC, and Greenberg EP. (1994) Quorum sensing in bacteria: the luxR-luxI family of cell density-responsive transcriptional regulators. $J$. Bacteriol. 176, 269-275.

11. Gismondo MR, Drago L, and Lombardi A. (1999) Review of probiotics available to modify gastrointestinal flora. Int. J. Antimicrob. Agents. 12, 287-292.

12. Hall IC, and O'Toole, E. (1935) Intestinal flora in new-born infants: with a description of a new pathogenic anaerobe, Bacillus difficilis. AMA. Am. J. Dis. Child. 49, 390-402.

13. Herrmann C, Ahmadian MR, Hofmann F, and Just I. (1998) Functional consequences of monoglucosylation of Ha-Ras at effector domain amino acid threonine 35. J. Biol. Chem. 273, 16134-16139.

14. Hundsberger T, Braun V, Weidmann M, Leukel P, Sauerborn M, and von Eichel-Streiber C. (1997) Transcription analysis of the genes $t c d A-E$ of the pathogenicity locus of Clostridium difficile. Eur. J. Biochem. 244, 735-742.

15. Jank T, Giesemann T, and Aktories K. (2007) Rhoglucosylating Clostridium difficile toxins A and B: new insights into structure and function. Glycobiology. 17, R15-22.

16. Katz JA. (2006) Probiotics for the prevention of antibiotic-associated diarrhea and Clostridium diarrhea. J. Clin. Gastroenterol. 40, 249-255.

17. Kekkonen R. (2008) Immunomodulatory effects of probiotic bacteria in healthy adults. World J. Gastroenterol. 14, 2029-2036.

18. Kelly CP, and LaMont JT. (2008) Clostridium difficilemore difficult than ever. N. Engl. Med. 359, 1932-1940.

19. Kuijper EJ, Barbut F, Brazier JS, Kleinkauf N, Eckmanns T, Lambert ML, Drudy D, Fitzpatrick F, Wiuff, C, Brown DJ, Coia JE, (2008) Update of Clostridium 
difficile infection due to PCR ribotype 027 in Europe, 2008. Euro. Suveill. 13, 7-9

20. Martin-Verstraete I, Peltier J, and Dupuy B. (2016) The regulatory networks that control Clostridium difficile toxin synthesis. Toxins. 8, 153-176.

21. McFarland LV. (2006) Meta-analysis of probiotics for the prevention of antibiotic associated diarrhea and the treatment of Clostridium difficile disease. Am. J. Gastroenterol. 101, 812-822.

22. Miller MB, and Bassler BL. (2001) Quorum sensing in bacteia. Annu. Rev. Microbiol. 55, 165-199.

23. Nealson KH, and Hastings JW. (1979) Bacterial bioluminescence: its control and ecological significance. Microbiol. Rev. 43, 496-518.

24. O'Connor JR, Johnson S, and Gerding DN. (2009) Clostridium difficile infection caused by the epidemic BI/NAP1/027 strain. Gastroenterology. 136, 1913-1924.

25. Ooi LG, and Liong MT. (2010) Cholesterol-lowering effects of probiotics and prebiotics: a review of in vivo and in vitro findings. Int. J. Mol. Sci. 11, 2499-2522.

26. Poutanen SM, and Simor AE. (2004) Clostridium difficile-associated diarrhea in adults. CMAJ. 171, 5158.

27. Quesada-Gomez C, Rodriguez C, Gamboa-Coronado MdelM, Rodriquez-Cavallini E, Du T, Mulvey MR., Villalobos-Zuniqa M, and Boza-Cordero R. (2010) Emergence of Clostridium difficile NAP1 in Latin America. J. Clin. Microbiol. 48, 669-670.

28. Rupnik M, Wilcox MH, and Gerding, DN. (2009) Clostridium difficile infection: new developments in epidemiology and pathogenesis. Nat. Rev. Microbiol. 7, 526-536.

29. Schroeder MS. (2005) Clostridium difficile-Associated diarrhea. Am. Fam. Physician. 71, 921-928.

30. Sehr P, Joseph G, Genth H, Just I, Pick E, and Aktories K. (1998) Glucosylation and ADP ribosylation of rho proteins: effects on nucleotide binding, GTPase activity, and effector coupling. Biochemistry. 37, 5296-5304.

31. Seo JG, Lee GS, Kim JE, and Chung MJ. (2010) Development of Probiotics Products and Challenges. K.S.B.B. 25, 303-310.

32. Shaughnessy MK, Micielli RL, Depestel DD, Arndt J, Strachan CL, and Chenoweth CE. (2011) Evaluation of hospital room assignment and acquisition of $\mathrm{Clo}^{-}$ stridium difficile infection. Infect. Control Hosp. Epidemiol. 32, 201-206.

33. Tae CH, Jung SA, Song HJ, Kim SE, Choi HJ, Lee M, Hwang Y, Kim H, and Lee K. (2009) The first case of antibioticassociated colitis by Clostridium difficile PCR ribotype 027 in Korea. J. Korean Med. Sci. 24, 520-524.

34. Tedesco FJ, Barton RW, and Alpers DH. (1974) Clindamycin-associated colitis: a prospective study. Ann. Intern. Med. 81, 429-433.

35. Warny M, Pepin J, Fang A, Killgore G, Thompson A, Brazier J, Frost E, and McDonald LC. (2005) Toxin production by an emerging strain of Clostridium difficile associated with outbreaks of severe disease in North America and Europe. Lancet. 366, 1079-1084.

36. Waters CM, and Bassler BL. (2005) Quorum semsing: cell-to-cell communication in bacteria. Annu. Rev. Cell Dev. Biol. 21, 319-346.

37. Xavier KB, and Bassler BL. (2003) LuxS quorum sensing: more than just a numbers game. Curr. Opin. Microbiol. 6, 191-197.

38. Zareie M, Johnson-Henry K, Jury J, Yang PC, Ngan BY, McKay DM, Soderholm JD, Perdue MH, and Sherman PM. (2006) Probiotics prevent bacterial translocation and improve intestinal barrier function in rats following chronic psychological stress. Gut. 55, 1553-1560.

39. Zilberberg MD, Tilotson GS, and McDonald C. (2010) Clostridium difficile infections among hospitalized children, united states, 1997-2006. Emerg. Infect. Dis. 16, 604-609. 